\title{
FinANCIAL DEVELOPMENT AND ECONOMIC GROWTH in The Presence of Simultaneity Bias: PANeL DATA EVIDENCE
}

\author{
OBINNA FRANKLIN EZEIBEKWE*
}

\begin{abstract}
Does financial development positively contribute to economic growth? One line of research argues that financial development is a positive contributor to growth. However, other studies show that financial development is not necessary for economic growth. An important contribution of this paper is that it estimates the correlation between financial development and economic growth after accounting for simultaneity bias. I employ the Principal Component Analysis to construct a composite financial development indicator based on four financial development variables. Due to the demand-following hypothesis which states that economic growth causes financial development, I conduct an endogeneity test on the composite financial development indicator and the results suggest that financial development is endogenous. Using the random effects instrumental variable estimation and the past values of the composite financial development indicator to account for simultaneity bias, I find that financial development remains a positive and relevant contributor to the long-run economic growth of developed countries.
\end{abstract}

Keywords: Financial development, Economic growth, Panel data econometrics, Principal component analysis, Instrumental variable, Simultaneity bias, Developed countries

JEL Classification: $O 16, E 44$

\section{INTRODUCTION}

Does financial development contribute significantly to economic growth in developed countries? To answer this question, this paper reviews the debate on the impact of financial development on economic growth and presents new empirical evidence on the relationship between financial development and economic growth for 10 developed countries after controlling for simultaneity bias using instrumental variable estimation and the past values of the financial development variable.

\footnotetext{
* Obinna Franklin Ezeibekwe, Eastern Illinois University, Charleston, IL, USA 61920, ofezeibekwe@eiu.edu; ezeibekweobinna@gmail.com
} 
Empirical results suggest that there are disagreements on how financial development affects economic growth and development. Some studies argue that financial development is integral for economic growth because of its fund mobilization and allocation functions. Authors such as Patrick (1966), Hicks (1969), and McKinnon (1973) propose that financial development drives economic growth through financial intermediation. In addition, a United Nations' World Economic Situation and Prospects 2018 report identified a strong financial architecture as crucial to actualizing balanced and sustainable growth because it ensures a steady provision of finance for industrialization.

However, other studies argue that financial development does not contribute significantly to economic growth. According to Lucas (1988), economists exaggerate the development impact of financial institutions. Similarly, Rousseau and Wachtel (2011) show that financial development is no longer a strong contributor to growth when a more current dataset is used as opposed to using data that covers the period from 1960 to 1989. Lastly, financial development negatively affects economic growth when bank credit to the private sector gets to $100 \%$ of GDP (Arcand et al. 2015).

Another argument that dominates the finance-growth literature is that of causation. Authors such as McKinnon (1973), and King and Levine (1993) are in support of the supply-leading hypothesis which stipulates that financial development drives economic growth. However, advocates of demand-following hypothesis posit that economic growth facilitates financial development by stimulating the financial sector to fund investments and growth. This notion has been supported by researchers such as Robinson (1952) and Hong, Torous, and Valkanov (2007).

More research needs to be conducted on the topic of financial development and economic growth (Levine, 1997) and given the potential of financial development to spur growth, it becomes imperative to estimate the correlation between financial development and economic growth in developed countries from 1980 to 2016. In this paper and in line with the literature, I construct a growth model with a composite financial development indicator, the key independent variable. The composite financial development indicator was constructed using four financial development indicators popular in the finance literature and they are broad money (liquid liabilities) as a percent of GDP (M3/GDP), domestic credit to the private sector by banks as a percent of GDP, stock market capitalization as a percent of GDP, and stock market turnover ratio (value traded divided by market capitalization). 
Some empirical works used one or two financial deepening indicators to proxy financial development. Here, I employ four financial development indicators to construct a composite financial development indicator because a single indicator is not capable of explaining financial development which contributes to economic growth through different mediums. Another key feature of this study that separates it from earlier studies is that it tests whether financial development is endogenous in the model (simultaneity bias). Also, I control for major determinants of growth such as gross fixed capital formation, labor force, government revenue (excluding grants) as a percent of GDP, trade openness, net inflows of foreign direct investment as a percent of GDP, and inflation rate. Therefore, I evaluate whether there is a significant positive correlation between financial development and economic growth of developed countries that is independent of other major variables associated with economic growth. Lastly, I use panel data for 10 developed countries that extend the period of analysis to 2016 to find out if the results of earlier studies are consistent with the present situation.

This paper will empirically answer the following question emanating from the arguments presented above. Does financial development contribute significantly to economic growth in developed countries in the presence of simultaneity bias? I employ different econometric methods to address the question posed by this study. First, I construct a composite financial development indicator using the principal component analysis. Then, I conduct a unit root test on the panel dataset to determine whether they are stationary or nonstationary. Having established that the variables are stationary at levels, I conduct endogeneity tests on the composite financial development indicator using the random and fixed effects methods presented by Wooldridge (2010). Both results suggest that the composite financial development indicator is endogenous. Therefore, I use the random effects instrumental variable estimation, selected by the Hausman test, and the past values of the financial development variable to determine the impact of financial development on the economic growth of developed countries. I find that, after controlling for major determinants of growth and accounting for simultaneity bias, financial development has a positive impact on the economic growth of developed countries, and the size of the impact is both statistically and economically significant.

The remainder of the paper is organized as follows. Section 2 presents the literature review and section 3 presents the data, model specification, and econometric methods. Results and discussion are reported in section 4. A final section gives the conclusion and recommendations. 


\section{LiteratURE REVIEW}

Since the groundbreaking works of Goldsmith (1969), McKinnon (1973), and Shaw (1973), the relationship between financial development and economic growth has remained a controversial topic and numerous empirical studies have been carried out to investigate the relationship (De Gregorio and Guidotti, 1995). This section presents the results of some of those studies on developed countries.

In a broad cross-section of 80 countries using data averaged over 1960-1989, King and Levine (1993) show that the financial system can promote economic growth for all economies. Specifically, financial development indicators are positively associated with economic efficiency improvement, physical capital accumulation, and RGDP per capita growth. Similarly, Beck and Levine (2004) investigate the impact of stock markets and banks on the economic growth of 40 countries using a panel data set for the period 1976 to 1998 using the generalized method of moments techniques developed for dynamic panels. They find that stock markets and banks positively influence economic growth and the results are not caused by endogeneity-induced bias.

Furthermore, Apergis et al. (2007) collected a panel dataset for 15 Organization for Economic Co-operation and Development (OECD) countries and 50 non-OECD countries over the period 1975 to 2000 to estimate the longrun relationship between financial development and economic growth. The result suggests that there are equilibrium and bidirectional relationship between financial development and economic growth. In addition, Rioja and Valev (2007) investigate the effects of financial development on the determinants of economic growth in developed and developing countries. Their hypothesis is that financial development may affect productivity and capital investment in different ways in developed and developing countries using panel data from 74 countries. Empirical results show that, in more developed countries, financial development is positively associated with productivity and growth; while the effect of financial development on economic growth occurs mainly through capital investment in less developed economies.

In summary, while most of the evidence points to the fact that financial development is a positive and significant contributor to growth; the magnitude of the effect of financial development on growth varies with different indicators used to proxy financial development or to construct a composite financial development indicator, sample size, data frequency, the mathematical form of the model, and the type of estimator used (Khan and Senhadji, 2000). 


\section{DAta, Model SPECification, AND ECONOMETRIC MethodS}

\subsection{Data}

This study employs annual panel data for 10 developed countries (based on United Nations classification) over the period 1980 to 2016, a period of 37 years. The 10 countries are Australia, Austria, France, Germany, Japan, Netherlands, Norway, Spain, Switzerland, and the United States of America. The data was collected from World Development Indicators compiled by the World Bank, Federal Reserve Economic Data (FRED) sourced from the Federal Reserve Bank of St. Louis website, Global Financial Data and IMF's International Financial Statistics.

To construct the composite financial development indicator, I collected data for the following financial development indicators: broad money (or liquid liabilities) as a percent of GDP, domestic credit to the private sector by banks as a percent of GDP, stock market capitalization as a percent of GDP, and stock market turnover ratio (computed as value traded divided by market capitalization). Broad money as a percent of GDP, measures the breadth of financial markets, domestic credit to the private sector by banks as a percent of GDP measures the financial strength (lending capabilities) of banking institutions in an economy, and stock market capitalization as a percent of GDP measures the extent of capital market development. The stock market turnover ratio measures the efficiency and/or liquidity (the ease of buying and selling shares) of stock markets and high turnover implies a low transaction cost (Levine and Zervos, 1996). All financial indicators used positively affect economic growth. Also, I collected data for control variables such as gross fixed capital formation, working population (labor force), government revenue (excluding grants) as a percent of GDP, trade openness, net inflows of foreign direct investment as a percent of GDP, inflation rate and the instrumental variable, gross domestic savings.

I employ the principal component analysis (PCA) to construct the composite financial development indicator used in this study (see OECD 2008). I adopt a composite financial development indicator because a single financial development indicator cannot capture the overall impact financial development has on economic growth and development. Therefore, I employ an indicator based on four financial development indicators to estimate the relationship between financial development and economic growth of developed countries.

I conduct the Kaiser-Meyer-Olkin sampling adequacy test to determine if the four financial development indicators are suitable for principal component analysis (Kaiser, 1974; Cerny and Kaiser, 1977). Since the KMO statistic is greater than 
0.5 , I conclude that the financial development indicators are adequate for PCA. The result of the KMO sampling adequacy test is presented in Table 1.

Table 1: Kaiser-Meyer-Olkin Sampling Adequacy Test

\begin{tabular}{|l|c|}
\hline VARIABLE & KMO \\
\hline$B R O A D$ & 0.6268 \\
\hline CREDIT & 0.6123 \\
\hline MKTCAP & 0.7893 \\
\hline TURNOVER & 0.7939 \\
\hline OVERALL & $\mathbf{0 . 6 5 6 3}$ \\
\hline
\end{tabular}

Source: Author's computation (2019)

\subsection{Theoretical Framework and Model Specification}

This work is based on Levine's 1997 study, Financial Development and Economic Growth: Views and Agenda, in two ways. First, I use some financial indicators identified in Levine (1997) to construct the composite financial development indicator used in this study. However, I included stock market capitalization of listed domestic companies as a percent of GDP to account for capital market development, and stock market turnover ratio to account for efficiency and/or liquidity of the capital market. Including these two variables improves the measurement of financial development. Second, I adopt the linear specification of the growth model which expresses economic growth indicators in terms of financial development indicators and control variables such as initial income (log), initial secondary school enrollment rate $(\log )$, inflation rate, government consumption expenditures to GDP ratio, and trade openness.

The empirically proven demand-following hypothesis which stipulates that economic growth facilitates financial development suggests that financial development may be endogenous. An implication of using an endogenous variable as an explanatory variable is that it creates the problem of endogeneity correlation between an explanatory variable and the error term which leads to biased and inconsistent coefficients (Wooldridge, 2013). To test and account for the possible endogeneity of the financial development variable, FINANCE, and drawing from the regression equation above, I specify the panel data simultaneous equation model of this study as

$$
\begin{aligned}
& R G D P_{i t}=\beta_{1} \text { FINANCE }_{i t}+\lambda_{1} \boldsymbol{X}_{i t}+U_{i 1}+\varepsilon_{i t 1} \\
& \text { FINANCE }_{i t}=\beta_{2} \text { SAVINGS }_{i t}+\lambda_{2} \boldsymbol{X}_{i t}+U_{i 2}+\varepsilon_{i t 2}
\end{aligned}
$$


Where (1) is the structural equation to be estimated and (2) is the reduced form equation that expresses the potentially endogenous FINANCE in terms of the exogenous explanatory variables in (2) and an instrumental variable, SAVINGS.

Where $\mathrm{i}=1,2, \mathrm{~N} ; \mathrm{t}=1,2, \mathrm{~T}$; i refers to number of countries, $\mathrm{t}$ refers to time period; $R G D P_{i t}(\log )$ is the level of gross domestic product after accounting for price changes in country "i" over the period "t"; FINANCE $E_{i t}$ is the composite financial development indicator in country "i" over the period " $\mathrm{t}$ " and $\beta_{1}$ is the estimated coefficient on FINANCE; $\boldsymbol{\lambda}_{1}$ is a vector of coefficients on the variables in $\boldsymbol{X} ; \boldsymbol{X}_{i t}$ is a vector of control variables on country " $\mathrm{i}$ " over the period "t". The control variables are considered important and relevant to developed economies and they include real gross fixed capital formation (log) which measures the amount of investments in capital goods; working population or labor force $(\log )$ measures the amount of a country's working-age population (people aged 15 to 64) and a proxy for labor force; government revenue, excluding grants, as a percent of GDP measures cash receipts from taxes, fines, fees, rent, and other revenues such as income from property or sales; trade openness, calculated as the sum of exports and imports as a percent of GDP, measures the relative importance of international trade in the economy of a country; net inflows of foreign direct investment as a percent of GDP measures the amount of capital inflow; and inflation rate. The instrumental variable, SAVINGS $(\log )$ measures the amount of household, business, and government savings. $U_{i}$ is the unobserved heterogeneity, and $\varepsilon_{i t}$ is the idiosyncratic error in country "i" over the period "t". I expect inflation to appear with a negative sign while the other regressors are expected to be positive.

According to a 2018 United Nations' report, World Economic Situation and Prospects, investment, measured by gross fixed capital formation, accounted for roughly 60 percent of the acceleration in global economic activity in 2017; protectionist tendencies have the potential of limiting world trade hence the importance of trade openness; and foreign direct investment remains the most stable form of capital flow in the world. I follow Levine and Zervos (1996) and Hassan et al. (2011) to control for the inflation rate in an economic growth model. Also, I follow Solow (1956) and Mankiw, Weil, and Romer (1992) to identify the labor force as a significant contributor to economic growth. I control for government revenue because it has been found to be a significant contributor to growth (Rubinson, 1977). SAVINGS is the instrumental variable because a higher level of gross domestic savings promotes financial development (Hassan et al., 2011). 


\subsection{Econometric Methodology}

First, I use the principal component analysis (PCA) to construct the composite financial indicator used in this study and the Kaiser-Meyer-Olkin sampling adequacy test certifies the suitability of the four financial development indicators for principal component analysis. This study employs pre-estimation analysis such as descriptive statistics and the Levin, Lin, and Chu unit root test. The descriptive statistics present a comparison of the means of selected variables used in this study for the 10 developed countries studied from 1980 to 2016 and the Levin, Lin, and Chu unit root test is applied to find out if the variables are stationary or nonstationary. Furthermore, I proceed by conducting endogeneity tests on FINANCE using the random and fixed effects methods presented by Wooldridge (2010). Due to the endogeneity introduced by the endogenous explanatory variable FINANCE, I employ the random effects instrumental variable estimation, selected by the Hausman test, and the past values of the financial development variable to estimate the structural equation.

\section{RESUlts AND DisCUSSION}

\subsection{Descriptive Statistics}

The characteristics of the distribution of the variables for all the countries are presented in Table 2 below. Real gross domestic product, investment, and the size of the labor force are expressed in natural logarithm. Skewness is a measure of asymmetry in a distribution. A perfectly symmetrical dataset (for example, a normal distribution) will have a skewness of zero. All the variables, except $F D$ Investment and inflation, are normally skewed since their skewness statistics are close to zero. Kurtosis measures the tailedness of a distribution. A normal distribution (mesokurtic) will have a kurtosis of 3. Since the kurtosis statistics of FD Investment exceed 3, it is leptokurtic (more outliers) relative to normal. The rest is platykurtic (fewer outliers) relative to normal. 


\subsection{Comparison of the Means of Selected Variables}

Table 2: Descriptive Statistics

Sample: $1980-2016$

\begin{tabular}{|c|c|c|c|c|c|c|c|c|}
\hline & RGDP $(\log )$ & FINANCE & $\begin{array}{l}\text { Investment } \\
(\log )\end{array}$ & $\begin{array}{l}\text { Labor Force } \\
\qquad(\log )\end{array}$ & $\begin{array}{l}\text { e Govt Rev } \\
\text { (\% of GDP) }\end{array}$ & $\begin{array}{c}\text { Trade } \\
\text { (\% of GDP) }\end{array}$ & $\begin{array}{l}\text { FD } \\
\text { Investm } \\
\text { ent (\% } \\
\text { of } \\
\text { GDP) }\end{array}$ & Inflation \\
\hline Mean & 27.83830 & $-2.08 \mathrm{E}-08$ & 26.33038 & 16.79959 & 28.54986 & 60.97170 & 5.111475 & 2.749651 \\
\hline Median & 27.53635 & 0.078792 & 26.06694 & 16.78106 & 26.84526 & 55.70860 & 1.732940 & 2.063679 \\
\hline Maximum & 30.45954 & 3.406712 & 28.83560 & 19.17800 & 51.01926 & 156.2967 & 87.44259 & 15.43445 \\
\hline Minimum & 26.01309 & -3.173395 & 24.53937 & 14.76244 & 9.511686 & 16.01388 & -7.388078 & -5.205030 \\
\hline Std. Dev. & 1.172534 & 1.569825 & 1.177848 & 1.289881 & 11.60042 & 31.81666 & 9.321023 & 3.012758 \\
\hline Skewness & 0.474917 & -0.051779 & 0.431867 & 0.136624 & 0.150168 & 0.686115 & 3.416477 & 1.467857 \\
\hline Kurtosis & 2.178887 & 1.867716 & 2.039608 & 1.839760 & 1.642510 & 2.855954 & 21.44291 & 5.681104 \\
\hline Observations & 370 & 370 & 370 & 370 & 370 & 370 & 370 & 370 \\
\hline
\end{tabular}

Source: Author's computation (2019)

This sub-section compares the means of selected variables used in this study for the 10 developed countries studied with a view to presenting how the variables differ across the 10 developed countries from 1980 to 2016. Figure 1 shows the means of RGDP growth rates of the countries studied. For the period under review, Australia has the highest mean of RGDP growth rates while Switzerland recorded the lowest. The mean of Japan's Broad money as a percent of GDP was recorded as the highest while Norway was the poorest in this category (Figure 2). Figure 3 illustrates that Switzerland has the highest mean value of credit to the private sector by banks as a percent of GDP and the USA recorded the lowest mean value. The mean of Switzerland's stock market capitalization as a percent of GDP was the highest at $149.3 \%$ while Austria, at 18\%, was the lowest (Figure 4).

Figure 5 shows that Switzerland and the USA have the highest turnover ratio while Australia got the lowest mean. This suggests that Switzerland and the USA have the most efficient and liquid stock markets among the 10 countries studied. The mean of Australia's labor force growth rate was the highest at $1.42 \%$ while Japan's was the lowest at $-0.07 \%$ (Figure 6). This result underlines the low birth 
rate in Japan. From Figure 7, Spain recorded the highest mean for the inflation rate, $4.9 \%$, while Japan's is the lowest at $0.3 \%$. The mean of US' net inflow of foreign direct investment as a percent of GDP was recorded as the highest while Japan's was the poorest in this category (Figure 8). Figure 9 illustrates that Norway has the highest mean value of government revenue (excluding grants) as a percent of GDP and Japan recorded the lowest mean value.

Fig. 1: Mean of REAL GDP Growth Rate (\%) by COUNTRY

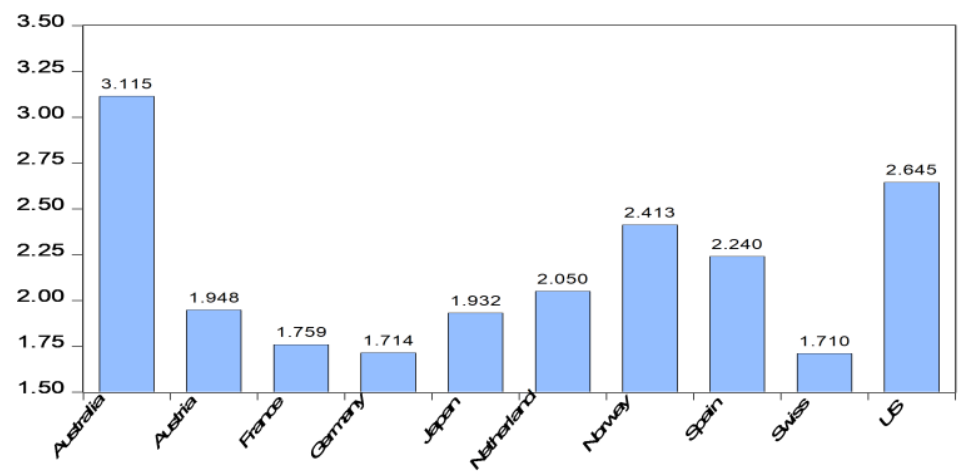

Fig. 2: Mean of Broad Money as a Percent of GDP by COUNTRY

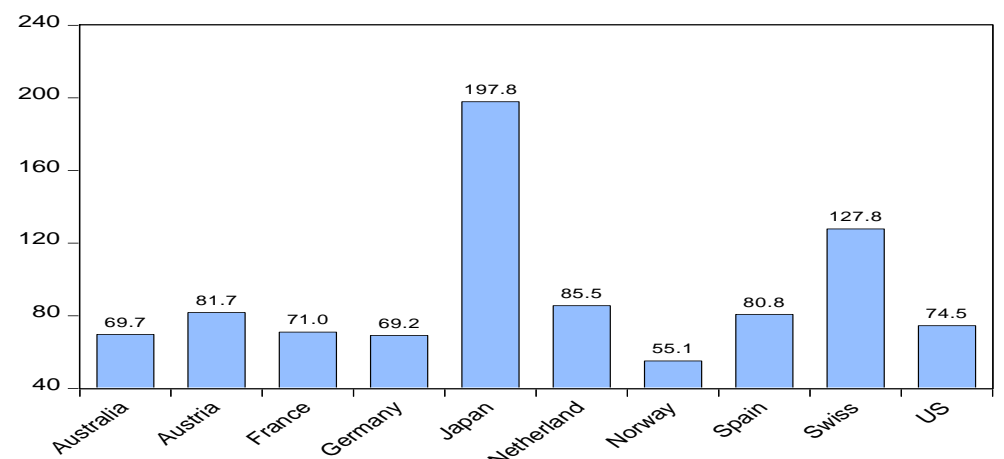

Fig. 3: Mean of Credit to Private Sector by banks as a Percent of GDP by COUNTRY

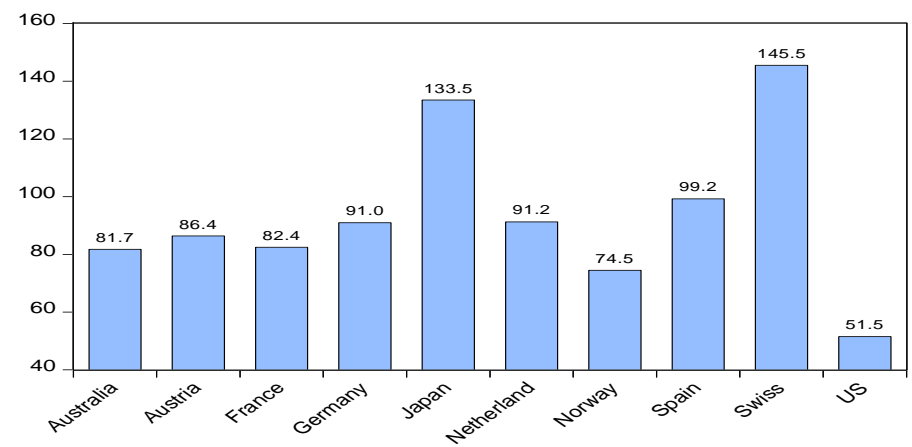


Fig. 4: Mean of Stock Market Capitalization as a percent of GDP by COUNTRY

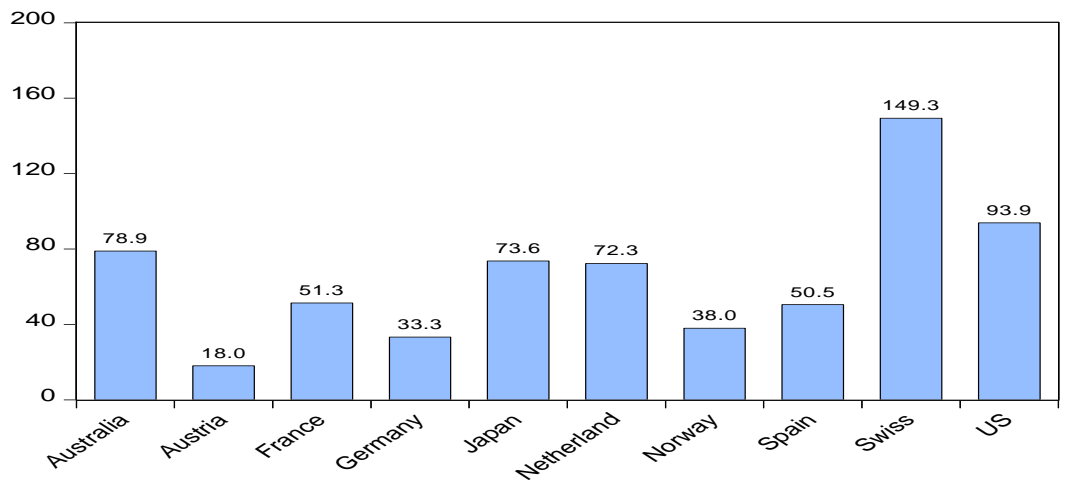

Fig. 5: Mean of Turnover Ratio by COUNTRY

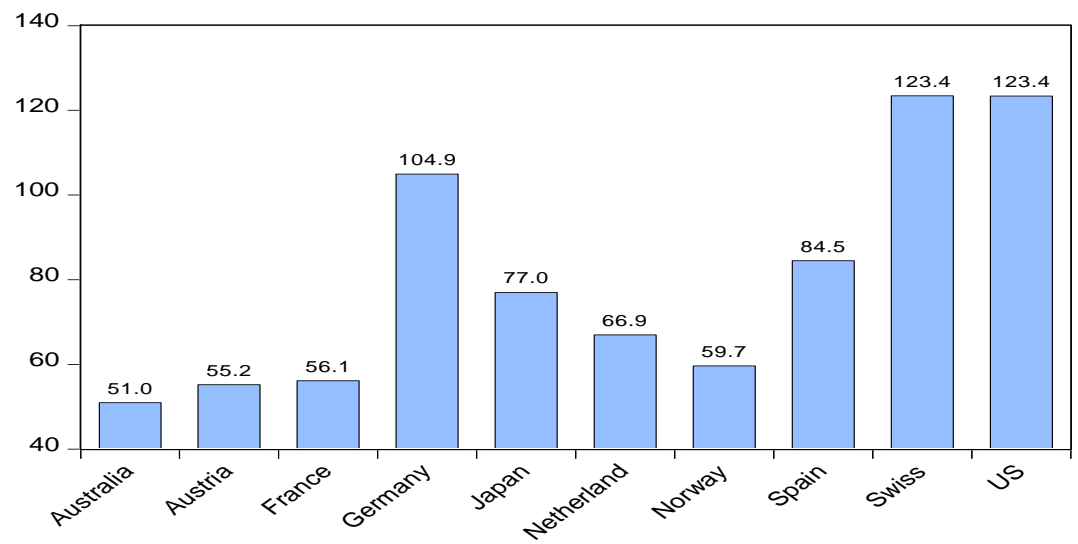

Fig. 6: Mean of Growth Rate of Labor Force (\%) by COUNTRY

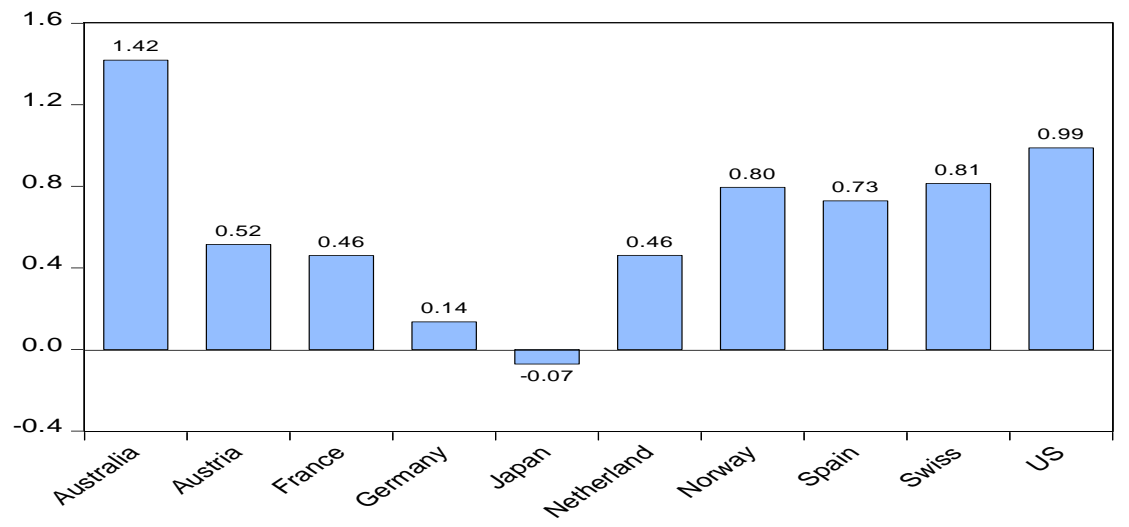


Fig. 7: Mean of Inflation Rate (\%) by COUNTRY

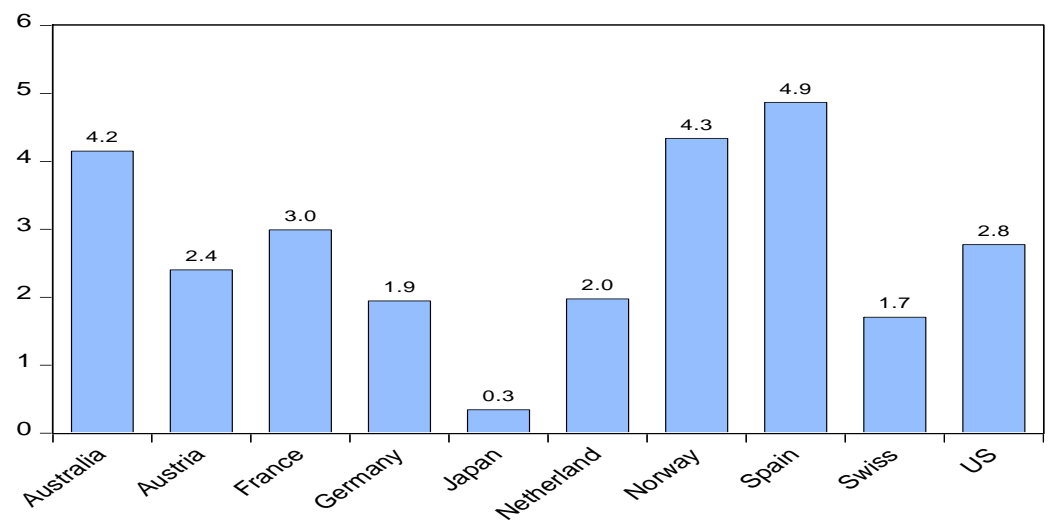

Fig. 8: Mean of Net Inflow of Foreign Direct Investment (\% of GDP) by COUNTRY

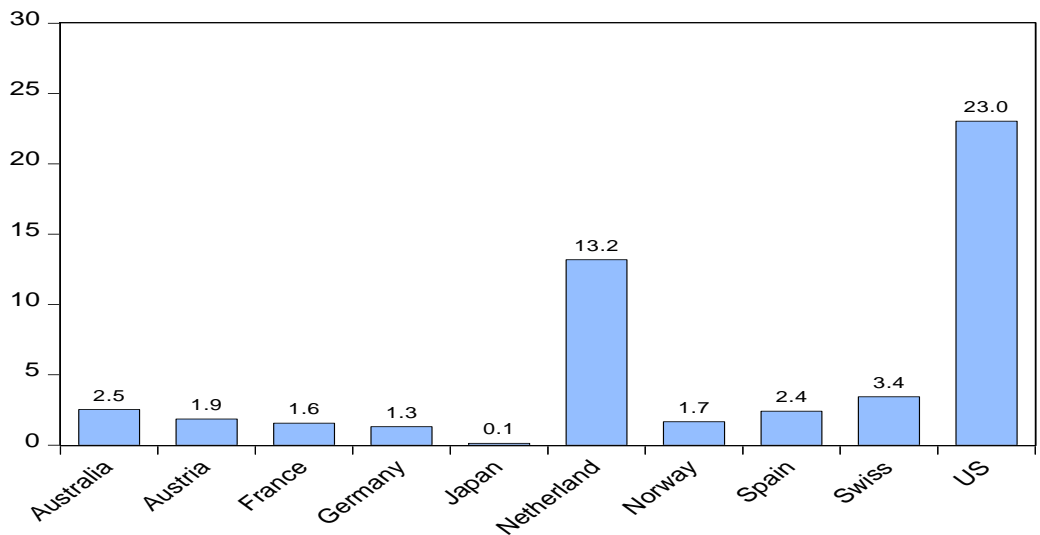

Fig. 9: Mean of Government Revenue as a Percent of GDP by COUNTRY

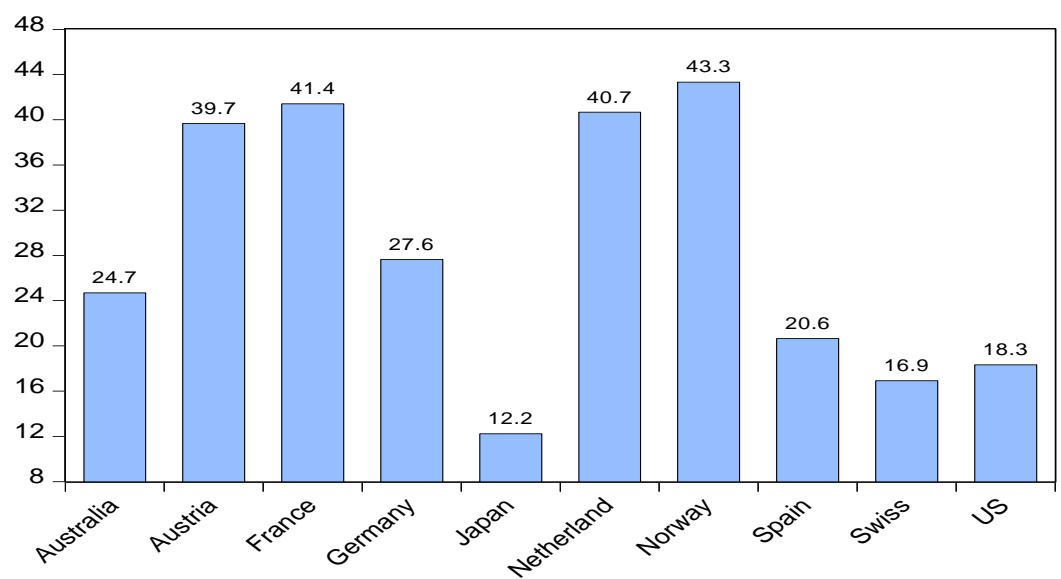

Source: Author's computations (2019) 


\subsection{Unit Root Test}

I employ the Levin, Lin, and Chu (LLC) unit root test to determine if the variables are stationary or non-stationary (see Levin, Lin, and Chu, 2002). The LLC test has as the null hypothesis that the panels contain a unit root and it assumes that the panels are balanced. The results of the LLC test, computed with the Schwarz information criterion, are presented in Table 3. The results show that all the variables are integrated of order zero, $I(0)$; that is, they are stationary (timeconstant means, variances, and autocorrelations) at levels. The implication of these results is that a regression involving these variables will not produce a spurious result since they are all stationary and there is no need for a cointegration (long-run or equilibrium) test (see Granger and Newbold 1974).

Table 3: Levin, Lin, and Chu (LLC) Unit Root Test

\begin{tabular}{|l|l|l|}
\hline \multicolumn{1}{|c|}{ Variable } & \multicolumn{1}{c|}{$\begin{array}{c}\text { LLC Statistic at } \\
\text { Level }\end{array}$} & \multicolumn{1}{c|}{ Order of Integration } \\
\hline RGDP $($ log $)$ & $-4.55424 * * *$ & $\mathrm{I}(0)$ \\
\hline FINANCE & $-1.36401^{*}$ & $\mathrm{I}(0)$ \\
\hline Investment $($ log) & $-2.20504 * *$ & $\mathrm{I}(0)$ \\
\hline Labor Force (log) & $-1.65114^{* *}$ & $\mathrm{I}(0)$ \\
\hline Government Revenue & $-1.79114^{* *}$ & $\mathrm{I}(0)$ \\
\hline Trade Openness & $-1.71464 * *$ & $\mathrm{I}(0)$ \\
\hline Foreign Direct Investment & $-2.67621^{* * *}$ & $\mathrm{I}(0)$ \\
\hline Inflation & $-6.53394 * * *$ & $\mathrm{I}(0)$ \\
\hline SAVINGS $($ IV) & $-1.70510^{* * *}$ & $\mathrm{I}(0)$ \\
\hline
\end{tabular}

Source: Author's computation (2019)

Note: $* * *, * *$, and $*$ denote stationary at $1 \%, 5 \%$, and $10 \%$ levels of significance respectively.

Trade Openness was detrended before it became stationary.

\subsection{Model Estimation}

I proceed by testing for the endogeneity of FINANCE using both the random effects and the fixed effects methods.

\subsubsection{Instrumental Variable Selection}

I use the endogeneity test presented by Wooldridge (2010) applicable to linear models. An advantage of these tests is that they are fully robust to serial correlation and heteroscedasticity. Before conducting an endogeneity test, an instrumental variable (IV) must be selected and the IV must meet two conditions to 
be a good IV. First, the IV must be correlated with the endogenous explanatory variable, FINANCE. This criterion suggests that the IV is strong. Second, the IV must not be directly correlated with the dependent variable, $R G D P$. The instrument chosen for the financial development variable is SAVINGS. I use (3) to test the first condition. SAVINGS is relevant and a strong IV if it is statistically different from zero. SAVINGS fulfills the second condition in that it does not directly affect the RGDP. This is true because the financial sector must allocate savings to different sectors for investment and growth to take place. This shows that a weak financial system negatively affects the impact of savings on the real economy.

\subsubsection{Endogeneity Tests Using Random and Fixed Effects Methods}

Testing for the endogeneity of FINANCE involves two steps. First, I estimate the reduced form of FINANCE using the random and fixed effects version of (2) and save the residuals.

The random and fixed effects versions of equation (2) are specified as (3) and (4) respectively:

$$
\begin{aligned}
& \text { FINANCE }_{i t}=\beta_{1} \text { SAVINGS }_{i t}+\lambda_{1} \boldsymbol{X}_{i t}+U_{i}+\varepsilon_{i t} \\
& \text { FINANCE }^{*}{ }_{i t}=\beta_{1} \text { SAVINGS }^{*}{ }_{i t}+\lambda_{1} \boldsymbol{X}^{*}{ }_{i t}+\varepsilon^{*}{ }_{i t}
\end{aligned}
$$

Second, I estimate the augment equations of random and fixed effects which entail controlling for the exogenous explanatory variables in (1) and the residuals from (3) and (4) but not including the IV, SAVINGS. If the residuals, RESIDUALI and RESIDUAL2, are statistically significant in both (5) and (6); then, FINANCE is endogenous, and an instrumental variable (SAVINGS) must be used to estimate the structural equation (1).

$$
\begin{aligned}
& R G D P_{i t}=\beta_{1} \text { FINANCE }_{i t}+\theta_{\mathrm{it}} R E S I D U A L 1_{i t}+\lambda_{1} X_{i t}+U_{i}+\varepsilon_{i t} \\
& R G D P *_{i t}=\beta_{1} \text { FINANCE }^{*}+\theta_{\mathrm{it}} R E S I D U A L 2{ }_{i t}+\lambda_{1} \boldsymbol{X}^{*}{ }_{i t}+\varepsilon^{*}{ }_{i t}
\end{aligned}
$$

The results of (3), (4), (5), and (6) are presented in Table 4 below. Regressions 1 and 3 present the results of the reduced form of the random effects (3) and fixed effects (4) respectively. As revealed, SAVINGS, the IV, is positively related to FINANCE and statistically significant in both the fixed and random effects. These suggest that SAVINGS is a relevant instrument and a strong IV. Regressions 2 and 4 present the results of the augment equations of the random effects (5) and fixed effects (6) respectively. Since RESIDUAL1 and RESIDUAL2 are statistically significant in both results, I conclude that FINANCE is indeed 
endogenous. Therefore, (1) must be estimated using an instrumental variable because it provides better estimates of the ceteris paribus effect of FINANCE on $R G D P$ when there is endogeneity (Wooldridge, 2013).

Table 4: Random and Fixed Effects Endogeneity Tests

\begin{tabular}{|c|c|c|c|c|}
\hline VARIABLES & $\begin{array}{c}(1) \\
\text { FINANCE } \\
\end{array}$ & $\begin{array}{c}\text { (2) } \\
R G D P(\log ) \\
\end{array}$ & $\begin{array}{c}(3) \\
\text { FINANCE } \\
\end{array}$ & $\begin{array}{c}(4) \\
R G D P(\log ) \\
\end{array}$ \\
\hline FINANCE & & $\begin{array}{c}0.157 * * * \\
(0.0458)\end{array}$ & & $\begin{array}{l}0.108 * * \\
(0.0436)\end{array}$ \\
\hline RESIDUALI & & $\begin{array}{c}-0.149 * * * \\
(0.0367)\end{array}$ & & \\
\hline Investment $(\log )$ & $\begin{array}{c}1.129 * * * \\
(0.382)\end{array}$ & $\begin{array}{c}0.416 * * * \\
(0.126)\end{array}$ & $\begin{array}{c}2.285^{* * * *} \\
(0.472)\end{array}$ & $\begin{array}{c}0.273 \\
(0.155)\end{array}$ \\
\hline Labor Force (log) & $\begin{array}{c}-1.603 * * * \\
(0.201)\end{array}$ & $\begin{array}{c}0.505 * * * \\
(0.108)\end{array}$ & $\begin{array}{c}1.848 \\
(1.447)\end{array}$ & $\begin{array}{c}0.225 \\
(0.482)\end{array}$ \\
\hline Govt. Revenue & $\begin{array}{c}0.0173 * * * \\
(0.00620)\end{array}$ & $\begin{array}{l}-0.00104 \\
(0.00152)\end{array}$ & $\begin{array}{c}-0.0148 \\
(0.0141)\end{array}$ & $\begin{array}{l}0.00465^{*} \\
(0.00224)\end{array}$ \\
\hline Trade & $\begin{array}{c}0.00294 \\
(0.00658)\end{array}$ & $\begin{array}{l}0.000422 \\
(0.00135)\end{array}$ & $\begin{array}{c}0.00924 \\
(0.00597)\end{array}$ & $\begin{array}{l}0.000370 \\
(0.00179)\end{array}$ \\
\hline FD Investment & $\begin{array}{c}0.0203 * * * \\
(0.00545)\end{array}$ & $\begin{array}{l}-0.000424 \\
(0.00258)\end{array}$ & $\begin{array}{c}0.0230 * * * \\
(0.00776)\end{array}$ & $\begin{array}{l}-0.000425 \\
(0.00159)\end{array}$ \\
\hline Inflation & $\begin{array}{c}-0.170 * * * \\
(0.0240)\end{array}$ & $\begin{array}{c}0.0181 * * * \\
(0.00653)\end{array}$ & $\begin{array}{c}-0.104 * * * \\
(0.0199)\end{array}$ & $\begin{array}{c}-0.00123 \\
(0.00321)\end{array}$ \\
\hline SAVINGS & $\begin{array}{c}0.781 * * * \\
(0.243)\end{array}$ & & $\begin{array}{c}0.923 * * * \\
(0.199)\end{array}$ & \\
\hline RESIDUAL2 & & & & $\begin{array}{c}-0.0687 * \\
(0.0345)\end{array}$ \\
\hline Constant & $\begin{array}{c}-23.48 * * * \\
(3.136)\end{array}$ & $\begin{array}{c}8.385^{* * * *} \\
(1.608)\end{array}$ & $\begin{array}{c}-114.9 * * * \\
(16.12)\end{array}$ & $\begin{array}{l}16.76^{*} \\
(8.069)\end{array}$ \\
\hline Observations & 370 & 370 & 370 & 370 \\
\hline R-squared & 0.449 & & 0.733 & 0.942 \\
\hline Number of id & & 10 & & 10 \\
\hline
\end{tabular}

Robust standard errors in parentheses

$* * * \mathrm{p}<0.01, * * \mathrm{p}<0.05, * \mathrm{p}<0.1$

\subsubsection{Hausman Test}

Having verified that the variables are stationary at levels and that FINANCE is endogenous, I estimate (1) using both the random and fixed effects with instrumental variable, SAVINGS, and employ the Hausman test to determine the efficient estimator (Wooldridge, 2010).

The Hausman test is a specification test developed for econometric model specifications and can be applied to an instrumental variable, panel data and simultaneous equation models (Hausman, 1978). For panel data models with 
instrumental variables, the null hypothesis is that the unobserved effects are not correlated with the instrumental variable.

The result of the Hausman test is presented in Table 5 below. The ChiSquare Statistic and the $p$-value of the test suggest that the random effects estimator is appropriate for the model.

Table 5: Hausman Test

\begin{tabular}{|c|c|c|c|}
\hline Variable & Fixed & Random & Var(Diff.) \\
\hline FINANCE & 0.1083911 & 0.1200574 & -0.0116663 \\
\hline Investment & 0.272557 & 0.1405242 & 0.1320328 \\
\hline Labor Force & 0.2247137 & 0.6519518 & -0.4272381 \\
\hline Government Revenue & 0.0046499 & 0.0043807 & 0.0002693 \\
\hline Trade Openness & 0.0003699 & 0.0006755 & -0.0003056 \\
\hline Foreign Direct Investment & -0.0004248 & -0.0008113 & 0.0003865 \\
\hline Inflation & -0.0012333 & 0.0020483 & -0.0032816 \\
\hline Test Summary & Chi-Sq. Statistic & Chi-Sq. d.f. & Prob. \\
\hline Cross-section random & 2.15 & 7 & 0.9313 \\
\hline
\end{tabular}

Source: Author's computation (2019)

\subsubsection{Random Effects Instrumental Variable Model}

The random effects instrumental variable estimation states that the unobserved heterogeneity, $U_{i}$, and the explanatory variables are not correlated. Due to endogeneity, I estimate (1) with an instrumental variable, SAVINGS.

The random effects instrumental variable model of equation (1) is specified as:

$$
R G D P_{i t}=\beta_{1} F_{I N A N C E}\left(\operatorname{SAVINGS}_{i t}\right)+\lambda_{1} \boldsymbol{X}_{i t}+U_{i}+\varepsilon_{i t}
$$

The result (7) is presented in Table 6. Regression (6) is the general model while regressions 1 through 5 are the parsimonious models.

Parsimonious model (5) best explains the economic growth of developed countries. There is a positive relationship between FINANCE and economic growth in all the models and the magnitudes of the effect are both statistically and economically significant even after controlling for other factors associated with economic growth and accounting for simultaneity bias. This finding confirms that financial development remains a significant contributor to growth and supports the argument that financial development is a significant contributor to growth in developed countries. Similarly, investment, the size of the labor force, and government revenue are all positively associated with economic growth and the sizes of the effects are both statistically and economically significant. The 
coefficient of government revenue is not as large as the coefficients of investment, labor force, and financial development.

Table 6: Random Effects Instrumental Variable Result (RGDP in log)

\begin{tabular}{|c|c|c|c|c|c|c|}
\hline VARIABLES & $\begin{array}{c}(1) \\
R G D P \\
\end{array}$ & $\begin{array}{c}(2) \\
R G D P \\
\end{array}$ & $\begin{array}{c}(3) \\
R G D P \\
\end{array}$ & $\begin{array}{c}(4) \\
R G D P \\
\end{array}$ & $\begin{array}{c}(5) \\
R G D P \\
\end{array}$ & $\begin{array}{c}(6) \\
R G D P \\
\end{array}$ \\
\hline FINANCE & $\begin{array}{c}0.114 * * * \\
(0.0269)\end{array}$ & $\begin{array}{c}0.135 * * * \\
(0.0321)\end{array}$ & $\begin{array}{c}0.113 * * * \\
(0.0239)\end{array}$ & $\begin{array}{c}0.110 * * * \\
(0.0235)\end{array}$ & $\begin{array}{c}0.108 * * * \\
(0.0228)\end{array}$ & $\begin{array}{c}0.120 * * * \\
(0.0266)\end{array}$ \\
\hline $\begin{array}{l}\text { Investment } \\
(\log )\end{array}$ & $\begin{array}{c}0.317 * * * \\
(0.118)\end{array}$ & $\begin{array}{l}0.0981 \\
(0.155)\end{array}$ & $\begin{array}{l}0.215^{*} \\
(0.112)\end{array}$ & $\begin{array}{c}0.233^{* *} \\
(0.105)\end{array}$ & $\begin{array}{l}0.275 * * * \\
(0.0910)\end{array}$ & $\begin{array}{l}0.141 \\
(0.119)\end{array}$ \\
\hline $\begin{array}{l}\text { Labor } \\
\underset{(\log )}{ }\end{array}$ & & $\begin{array}{c}0.498 * * * \\
(0.126)\end{array}$ & $\begin{array}{c}0.391 * * * \\
(0.116)\end{array}$ & $\begin{array}{c}0.364 * * * \\
(0.125)\end{array}$ & $\begin{array}{l}0.250 * \\
(0.149)\end{array}$ & $\begin{array}{c}0.652 * * * \\
(0.111)\end{array}$ \\
\hline Govt. Revenue & & & $\begin{array}{c}0.00461 * * * \\
(0.00145)\end{array}$ & $\begin{array}{c}0.00470 * * * \\
(0.00142)\end{array}$ & $\begin{array}{c}0.00456 * * * \\
(0.00138)\end{array}$ & $\begin{array}{r}0.00438^{* * * *} \\
(0.00151)\end{array}$ \\
\hline $\begin{array}{l}\text { Trade } \\
\quad \text { Openness }\end{array}$ & & & & 0.000365 & 0.000342 & 0.000676 \\
\hline FD Investment & & & & $(0.000624)$ & $\begin{array}{c}(0.000616) \\
-0.000451 \\
(0.000923)\end{array}$ & $\begin{array}{c}(0.000672) \\
-0.000811 \\
(0.00111)\end{array}$ \\
\hline Inflation & & & & & & $\begin{array}{c}0.00205 \\
(0.00375)\end{array}$ \\
\hline Constant & $\begin{array}{c}19.50 * * * \\
(3.108)\end{array}$ & $\begin{array}{c}16.89 * * * \\
(3.428)\end{array}$ & $\begin{array}{c}15.47 * * * \\
(2.934)\end{array}$ & $\begin{array}{c}15.44 * * * \\
(3.175)\end{array}$ & $\begin{array}{c}16.26 * * * \\
(4.649)\end{array}$ & $\begin{array}{c}13.06 * * * \\
(1.961)\end{array}$ \\
\hline Observations & 370 & 370 & 370 & 370 & 370 & 370 \\
\hline Number of id & 10 & 10 & 10 & 10 & 10 & 10 \\
\hline
\end{tabular}

Standard errors in parentheses

$* * * \mathrm{p}<0.01, * * \mathrm{p}<0.05, * \mathrm{p}<0.1$

\subsubsection{Controlling for Simultaneity Bias Using the Past Values of FINANCE}

So far, I have attempted to control for simultaneity bias using an instrumental variable. Another popular method of controlling for simultaneity bias is by using the lagged values of the endogenous variable.

The random effects model of equation (1) with the composite financial development indicator in lag is specified as:

$$
R G D P_{i t}=\beta_{1} F_{I N A N C E_{i t-1}}+\lambda_{1} \boldsymbol{X}_{i t}+U_{i}+\varepsilon_{i t}
$$

The result of (8) is presented in Table 7. Regression (6) is the general model while regressions 1 through 5 are the parsimonious models. Like the IV estimation, financial development is positively and robustly correlated with economic growth in all the models. 
Table 7: Random Effects Result Using Lagged Values of FINANCE (RGDP in log)

\begin{tabular}{|c|c|c|c|c|c|c|}
\hline VARIABLES & $\begin{array}{c}(1) \\
R G D P\end{array}$ & $\begin{array}{c}(2) \\
R G D P\end{array}$ & $\begin{array}{c}(3) \\
R G D P\end{array}$ & $\begin{array}{c}(4) \\
R G D P\end{array}$ & $\begin{array}{c}(5) \\
R G D P\end{array}$ & $\begin{array}{c}(6) \\
R G D P\end{array}$ \\
\hline FINANCE $E_{t-1}$ & $\begin{array}{c}0.0307 * * * \\
(0.0118)\end{array}$ & $\begin{array}{c}0.0469 * * * \\
(0.0102)\end{array}$ & $\begin{array}{c}0.0472 * * * \\
(0.0105)\end{array}$ & $\begin{array}{c}0.0469 * * * \\
(0.0114)\end{array}$ & $\begin{array}{c}0.0461 * * * \\
(0.0113)\end{array}$ & $\begin{array}{l}0.0244 * \\
(0.0135)\end{array}$ \\
\hline $\begin{array}{c}\text { Investment } \\
(\log )\end{array}$ & $0.712 * * *$ & $0.498 * * *$ & $0.491 * * *$ & $0.492 * * *$ & $0.486 * * *$ & $0.620 * * *$ \\
\hline $\begin{array}{c}\text { Labor } \\
(\log )\end{array}$ & $(0.0739)$ & $\begin{array}{c}(0.0665) \\
0.423 * * *\end{array}$ & $\begin{array}{c}(0.0656) \\
0.441 * * *\end{array}$ & $\begin{array}{l}(0.0655) \\
0.447 * * *\end{array}$ & $\begin{array}{c}(0.0665) \\
0.451 * * *\end{array}$ & $\begin{array}{l}(0.0735) \\
0.333 * * *\end{array}$ \\
\hline & & $(0.0589)$ & $(0.0645)$ & $(0.0681)$ & $(0.0662)$ & $(0.0615)$ \\
\hline Govt. Revenue & & & $\begin{array}{c}0.00270 \\
(0.00217)\end{array}$ & $\begin{array}{c}0.00303 \\
(0.00219)\end{array}$ & $\begin{array}{c}0.00320 \\
(0.00217)\end{array}$ & $\begin{array}{c}0.00199 \\
(0.00203)\end{array}$ \\
\hline Trade Openness & & & & $\begin{array}{c}0.00117 \\
(0.00163)\end{array}$ & $\begin{array}{l}0.000962 \\
(0.00170)\end{array}$ & $\begin{array}{c}0.00117 \\
(0.00160)\end{array}$ \\
\hline FD Investment & & & & & $\begin{array}{c}0.00108 \\
(0.000787)\end{array}$ & $\begin{array}{c}0.00211 \\
(0.00181)\end{array}$ \\
\hline Inflation & & & & & & $\begin{array}{c}-0.00565^{* * * *} \\
(0.00167)\end{array}$ \\
\hline Constant & $\begin{array}{c}9.102 * * * \\
(1.917)\end{array}$ & $\begin{array}{c}7.626 * * * \\
(1.374)\end{array}$ & $\begin{array}{c}7.437 * * * \\
(1.429)\end{array}$ & $\begin{array}{c}7.309 * * * \\
(1.562)\end{array}$ & $\begin{array}{c}7.375^{* * * *} \\
(1.515)\end{array}$ & $\begin{array}{c}5.884 * * * \\
(1.210)\end{array}$ \\
\hline Observations & 360 & 360 & 360 & 360 & 360 & 360 \\
\hline Number of id & 10 & 10 & 10 & 10 & 10 & 10 \\
\hline
\end{tabular}

Robust standard errors in parentheses

$* * * \mathrm{p}<0.01, * * \mathrm{p}<0.05, * \mathrm{p}<0.1$

\section{CONCLUSION AND RECOMMENDATION}

This paper investigated the impact of financial development on the economic growth of 10 developed countries from 1980 to 2016 in the presence of simultaneity bias. Given the demand-following hypothesis, I conduct the endogeneity test on FINANCE using the random and fixed effects endogeneity test. Due to the simultaneity bias introduced by the endogenous explanatory variable FINANCE, I employ an instrumental variable estimation and the past values of the composite financial development indicator to estimate the correlation between financial development and economic growth. I find that, after controlling for major determinants of economic growth in developed countries and accounting for simultaneity bias, financial development remains a positive and significant contributor to long-run economic growth in developed countries, and the size of the impact is both statistically and economically significant.

The policy implication of this result is that policymakers in developed countries should continue to prioritize policies that ensure financial development 
since it has the capability of boosting long-run economic growth. Although this paper has improved our understanding of the nature of the relationship between financial development and economic growth in developed countries, more work remains to be done on financial development (Levine, 1997). Specifically, economists must provide more practical answers to the following questions. Why do countries in the same income bracket have different looking financial structures (suggested by sub-section 4.2. of this study) and what are its implications for developing countries hoping to achieve financial development? Answers to these questions will improve our understanding of how countries can achieve financial development that can boost sustainable development in both developed and developing countries.

Acknowledgment: My profound gratitude to Emeritus Professor Mukti Upadhyay for supervising this work and for his invaluable comments. I thank the participants at the 2019 Missouri Valley Economic Association (MVEA) conference for their feedback. 


\section{REFERENCES}

1. Apergis, N., Filippidis, I., and Economidou, C. (2007). Financial Deepening and Economic Growth Linkages: A Panel Data Analysis. Review of World Economics, 143(1): 179-198.

2. Arcand, J., Berkes, E., and Panizza, U. (2015). Too Much Finance? Journal of Economic Growth, 20(2): 105-148.

3. Beck, T. and Levine, R. (2004). Stock Markets, Banks, and Growth: Panel Evidence. Journal of Banking \& Finance, 28, 423-442.

4. Cerny, B. and Kaiser, H. (1977). A Study of a Measure of Sampling Adequacy for Factor-Analytic Correlation Matrices. Multivariate Behavioral Research., 12(1): 43-47.

5. De Gregorio, J. and Guidotti, P. (1995). Financial Development and Economic Growth. World Development, 23(3): 433-448.

6. Goldsmith, R. (1969). Financial Structure and Development. New Haven, CT: Yale Univerity Press.

7. Granger, C. and Newbold, P. (1974). Spurious Regressions in Econometrics. Journal of Econometrics, 2(2): 111-120.

8. Hassan, M. K., Sanchez, B., and Yu, J. (2011). Financial Development and Economic Growth: New Evidence from Panel Data. Quarterly Review of Economics and Finance, 51(1): 88-104.

9. Hausman, J. (1978). Specification Tests in Econometrics. Econometrica, 46(6): 1251-1271.

10. Hicks, J. (1956). A Theory of Economic History. Oxford: Clarendon Press.

11. Kaiser, H. (1974). An Index of Factorial Simplicity. Psychometrika, 39(1):3136.

12. Khan, M. and Senhadji (2000). Financial Development and Economic Growth: An Overview. IMF Working Paper WP/00/209

13. King, R. and Levine, R. (1993). Finance and Growth: Schumpeter Might be Right. Quarterly Journal of Economics, 108(3): 717-738.

14. Levin, A., Lin, C., and Chu, C. (2002). Unit Root Tests in Panel Data: Asymptotic and Finite-Sample Properties. Journal of Econometrics, 108(1): 124.

15. Levine, R. (1997). Financial Development and Economic Growth: Views and Agenda. Journal of Economic Literature, 35(2): 688-726.

16. Levine, R. and Zervos, S. (1996). Stock Market Development and Long-Run Growth. The World Bank Economic Review, 10(2): 323-339. 
17. Lucas, R. (1988). On the Mechanics of Economic Growth. Journal of Monetary Economics, 22(1): 3-42.

18. Mankiw, N., Romer, P., and Weil, D. (1992). A Contribution to the Empirics of Economic Growth. The Quarterly Journal of Economics, 107(2):407-437.

19. McKinnon, R. (1973). Money and Capital in Economic Development. Washington DC: Brookings Institution.

20. Patrick, H. (1966). Financial Development and Economic Growth in Underdeveloped Countries. Economic Development and Cultural Change, 14(2): 174-189.

21. Rioja, F. and Valev, N. (2004). Finance and the Sources of Growth at Various Stages of Economic Growth. Economic Inquiry, 42(1): 127-140.

22. Robinson, J. (1952). The Generalization of the General Theory. In the Rate of Interest and Other Essays. London: Macmillan Press.

23. Rousseau, P. and Wachtel, P. (2011). What is Happening to the Impact of Financial Deepening on Economic Growth? Economic Inquiry, 49(1): 276-288.

24. Rubinson, R. (1977). Dependence, Government Revenue, and Economic Growth., 1955-1970. Studies In Comparative International Development, 12(2): 3-28.

25. Shaw, E. (1973). Financial Deepening in Economic Development. New York: Oxford University Press.

26. Solow, R. (1956). A Contribution to the Theory of Economic Growth. The Quarterly Journal of Economics, 70(1): 65-94.

27. Torous, W., Valkanov, R., and Hong, H. (2007). Do Industries Lead Stock Markets? Journal of Financial Economics, 83(2): 367-396.

28. United Nations (2018). World Economic Situation and Prospects. Retrieved from https://www.un.org/development/desa/dpad/wpcontent/uploads/sites/45/publication/WESP2018_Full_Web-1.pdf

29. Wooldridge, J. (2010). Econometric Analysis of Cross Section and Panel Data (2nd ed.). Cambridge, MA: Massachusetts Institute of Technology Press.

30. Wooldridge, J. (2013). Introductory Econometrics: A Modern Approach (5th ed.). Mason, OH: South-Western, Cengage Learning. 